\title{
L-Triiodothyronine Stimulates Growth by Means of an Autocrine Factor in a Cultured Growth Hormone-producing Cell Line
}

\author{
Michael J. Miller, Elizabeth C. Fels, Lawrence E. Shapiro, and Martin I. Surks \\ Division of Endocrinology and Metabolism, Department of Medicine, Montefiore Medical Center \\ and the Albert Einstein College of Medicine, Bronx, New York 10467
}

\begin{abstract}
L-Triodothyronine $\left(T_{3}\right)$ stimulates DNA synthesis and replication of cultured GC cells, a $T_{3}$-responsive growth hormone (GH)-secreting cell line. To determine whether $T_{3}$ stimulates secretion of an autocrine growth factor, we compared the growthpromoting activity of medium conditioned by $T_{3}$-stimulated and $T_{3}$-depleted cells to that of unconditioned medium. Addition of polyclonal rabbit anti- $T_{3}$ serum to $T_{3}$-containing media decreased cellular $\mathrm{T}_{3}$ content by $\mathbf{5 0 - 7 0 \%}$. In unconditioned medium, anti$T_{3}$ serum decreased $T_{3}$-induced cell growth and $G H$ production by $40-70 \%$. In conditioned medium, anti- $\mathrm{T}_{3}$ serum also effected a $45-70 \%$ decrease in induction of GH secretion but did not attenuate the growth-promoting activity. Growth-promoting activity was not detected in medium conditioned by $T_{3}$-depleted cells. Thus, conditioned medium from $\mathrm{T}_{3}$-containing $\mathbf{G C}$ cell cultures contains growth-promoting activity that is independent of $T_{3}$. Further, the induction of GC cell growth by $T_{3}$ may occur, at least in part, by induction of an autocrine growth factor.
\end{abstract}

\section{Introduction}

Thyroid hormone is an absolute requirement for normal growth and development of many tissues (1-7); the nervous system is particularly sensitive to this hormonal effect (8-11). Although critical for cell growth, these previously reported experimental systems have not been developed to a sufficient extent to elucidate the mechanism by which thyroid hormone regulates growth (1-11). We have demonstrated that the anterior pituitary of hypothyroid rats has a $70 \%$ reduction in number of somatotrophs, the cell line that synthesizes and secretes growth hormone $(\mathrm{GH})^{1}(12)$. When hypothyroid rats were injected with $3,5,3^{\prime}$ triiodo-L-thyronine $\left(\mathrm{T}_{3}\right)$, we observed a marked increase in the rate of DNA synthesis of the somatotrophs after 2-5 d (13) and a complete restoration to normal of the somatotroph population

\footnotetext{
Address reprint requests to Dr. Surks.

Presented in part at the Annual Meeting of the Association of American Physicians, 2 May 1986 in Washington DC, and published in abstract form (1986. Clin. Res. 34:714a).

Received for publication 9 June 1986 and in revised form 3 February 1987.
}

1. Abbreviations used in this paper: DME, Dulbecco's modified Eagle's medium; EGF, epidermal growth factor; GC, cultured growth hormoneproducing cells; $\mathrm{GH}$, growth hormone; IGF, insulinlike growth factor; NGF, nerve growth factor; SMG, submandibular gland.

J. Clin. Invest.

(c) The American Society for Clinical Investigation, Inc.

0021-9738/87/06/1773/09 $\$ 1.00$

Volume 79, June 1987, 1773-1781 after 5-10 d (14). These findings suggested that the growth of somatotrophs was regulated by thyroid hormone.

More recently, we have shown that cultures of GC cells, a cell line that was cloned from a rat somatotrophic tumor, provide a useful experimental model for more detailed studies of $T_{3}$ effects on cell growth than can be performed in vivo. Similar to the somatotrophs in vivo, GC cells require thyroid hormone for optimal growth (15) as well as for $\mathrm{GH}$ production $(16,17)$. Although $\mathrm{GH}$ is induced by $\mathrm{T}_{3}$, the secreted $\mathrm{GH}$ does not appear responsible for the hormonal induction of GC cell growth (15). The doubling time of asynchronous populations of GC cells is 30-35 $\mathrm{h}$ in the presence of $0.18 \mathrm{nM} \mathrm{T} \mathrm{T}_{3}$. This is a physiologic $\mathrm{T}_{3}$ concentration that results in one-half saturation of the iodothyronine nuclear receptor (16). The doubling time is increased to $100-120 \mathrm{~h}$ in cultures maintained in $\mathrm{T}_{3}$-depleted medium (10 pM) $(15,18)$. We have previously reported that the growth-promoting action of $T_{3}$ in cultured GC cells occurs during the first 4-6 $h$ of the $G_{1}$ period, has dose-response characteristics that suggest mediation by the nuclear iodothyronine receptor and requires protein synthesis $(19,20)$. These findings suggested that $T_{3}$ might stimulate growth by induction of specific regulatory protein(s) during the early $G_{1}$ period. We have now investigated the possibility that stimulation of growth by $T_{3}$ may be mediated by a secreted protein(s) that functions as an autocrine growth factor. To test this hypothesis, we studied the induction of GC cell growth in conditioned medium from $T_{3}$-stimulated and $T_{3}$ depleted GC cell cultures and compared these responses to those of unconditioned medium.

\section{Methods}

Preparation of conditioned medium. Monolayer cultures of GC cells were maintained in Dulbecco's modified Eagle's medium (DME) supplemented with 10\% serum (calf/horse, 2:1) (Gibco Laboratories, Grand Island, NY) in $75 \mathrm{~cm}^{2}$ tissue culture flasks (Lux Laboratory Plastics, Miles Scientific, Naperville, IL). The plating density was $1.0 \times 10^{6}$ to $1.4 \times 10^{6}$ cells per flask. All cell culture was performed in a $5 \% \mathrm{CO}_{2}$ atmosphere at $37^{\circ} \mathrm{C}$. The concentration of $\mathrm{T}_{3}$ in total medium was 0.3 $\mathrm{nM}$ (15). When cultures had attained a density of 7-9 $\times 10^{6}$ cells per flask, medium ( $12 \mathrm{ml} /$ flask) was exchanged for DME, which was supplemented with $10 \%$ thyroidectomized calf serum (Rockland Animal Farms, Gilbertsville, PA) with added $\mathrm{T}_{3}(0.2 \mathrm{nM}$ in complete medium). The thyroidectomized calf serum had previously been treated with Dowex $1 \times 8400$ anion exchange resin by the method of Samuels et al. (21) to insure complete removal of endogenous thyroid hormones. After treatment with resin, the $T_{3}(22)$ and $T_{4}$ (Clinical Assays, Cambridge, MA) concentrations of the thyroidectomized calf serum were $<50 \mathrm{pM}$ and $1.3 \mathrm{nM}$, respectively. Conditioned medium produced during subsequent log-phase growth was collected after $24 \mathrm{~h}$ when cell density had increased to $\sim 15 \times 10^{6}$ cells per flask.

Conditioned medium was also collected from cultures that were maintained under $\mathrm{T}_{3}$-depleted conditions for at least $48 \mathrm{~h}$. For these studies, medium was exchanged for DME containing $10 \%$ thyroidecto- 
mized calf serum that was not supplemented with $T_{3}\left(T_{3}\right.$ concentration, $5 \mathrm{pM}$ in complete medium) $2 \mathrm{~d}$ before beginning the 24-h collection of conditioned medium. Cell density was adjusted to be comparable to those cultures employed for collection of conditioned medium in the presence of $0.2 \mathrm{nM} \mathrm{T}_{3}$, as indicated above.

Anti- $T_{3}$ serum. To determine the growth promoting activity of conditioned medium containing physiologic concentrations of $T_{3}(0.2 n M)$, it was necessary either to remove $T_{3}$ from the medium or reduce its biological activity. This was accomplished by addition of rabbit anti- $\mathrm{T}_{3}$ serum to the conditioned medium to reduce cellular $T_{3}$. Rabbit anti- $T_{3}$ serum was developed by injection of a $T_{3}$-albumin conjugate as described previously (22). To titrate the concentration of anti- $T_{3}$ serum against cellular $T_{3}$ content, cultures of GC cells were maintained in DME containing $10 \%$ serum (calf/horse, 2:1) in $60 \mathrm{~mm}$ diam tissue culture plates as previously described (15). The $T_{3}$ concentration in complete medium was $0.3 \mathrm{nM}$. Measurements of the effect of anti- $T_{3}$ serum on $T_{3}$ distribution were carried out when cells had grown to a density of $2.5 \times 10^{6}$ per plate. Medium was then decanted and replaced with fresh medium supplemented with varying amounts of normal rabbit serum or rabbit anti- $\mathrm{T}_{3}$ serum and $0.1 \mathrm{nM}\left[{ }^{125} \mathrm{I}\right]$ triiodo-L-thyronine [Abbott Laboratories, North Chicago, IL; 450-550 $\mu \mathrm{Ci} / \mu \mathrm{g}$ sp act $]\left(\left[{ }^{125} \mathrm{I}\right] \mathrm{T}_{3}\right)$. After $\left[{ }^{125} \mathrm{I}\right] \mathrm{T}_{3}$ was incubated for $3 \mathrm{~h}$ to allow equilibration with all cellular compartments (23), media were decanted and the cells were rinsed briefly first with 0.14 $\mathrm{M} \mathrm{NaCl}$ and then with $0.25 \mathrm{M}$ sucrose, $20 \mathrm{mM}$ Tris- $\mathrm{HCl}, 1.1 \mathrm{mM} \mathrm{MgCl}_{2}$, $\mathrm{pH}\left(25^{\circ} \mathrm{C}\right) 7.85$. Cells were harvested by scraping in $50 \mathrm{mM}$ Tris- $\mathrm{HCl}$, $1.1 \mathrm{mM} \mathrm{MgCl}_{2}, 0.5 \%$ Triton X-100, $\mathrm{pH}\left(25^{\circ} \mathrm{C}\right) 7.85$ at $0-5^{\circ} \mathrm{C}$ followed by mixing and centrifugation to separate intact nuclei from cytosol (23). Cellular $\left[{ }^{125} \mathrm{I}\right] \mathrm{T}_{3}$ was corrected for nonspecifically bound $\left[{ }^{125} \mathrm{I}\right] \mathrm{T}_{3}$, which was determined in parallel plates of GC cells incubated with $0.1 \mathrm{nM}^{125} \mathrm{I}$ supplemented with a 500-fold molar excess of nonradioactive $T_{3}(23)$. In other studies, we have shown that there is no appreciable metabolism of $\left[{ }^{125} \mathrm{I}\right] \mathrm{T}_{3}$ under the conditions of this experiment $(15,20)$.

Assay of growth-promoting activity. Growth-promoting activity of conditioned medium was determined in GC cell cultures that were maintained in $\mathrm{T}_{3}$-depleted conditions. Cells were plated at a density of $125,000 / 25 \mathrm{~cm}^{2}$ flasks in DME containing 10\% serum (calf/horse, $2: 1$ ). After $24 \mathrm{~h}$, medium was exchanged for DME containing $10 \%$ resintreated thyroidectomized calf serum $\left(\mathrm{T}_{3}, 5 \mathrm{pM}\right)$. After $72 \mathrm{~h}$, medium was removed and then replaced with experimental medium. In general, five experimental conditions were studied: unconditioned medium containing 10\% resin-treated thyroidectomized calf serum; unconditioned medium containing $10 \%$ resin-treated thyroidectomized calf serum supplemented with $\mathrm{T}_{3}(0.2 \mathrm{nM})$ and either anti- $\mathrm{T}_{3}$ serum or normal rabbit serum $\left(5 \mu \mathrm{l} / \mathrm{ml}\right.$ medium) and conditioned medium $\left(0.2 \mathrm{nM} \mathrm{T}_{3}\right)$ containing either anti- $\mathrm{T}_{3}$ serum or normal rabbit serum $(5 \mu \mathrm{l} / \mathrm{ml}$ medium). Cultures were refed with the respective experimental media after 48-72 $\mathrm{h}$ and cells were harvested for DNA determination after an additional 48-72 $\mathrm{h}$ (total, $120 \mathrm{~h}$ in experimental media). Similar results were obtained when growth rates were studied between $72 \mathrm{~h}$ and $120 \mathrm{~h}$ of incubation in experimental media. In some experiments, media from the last 48-72 h of culture with experimental media were retained for determination of $\mathrm{GH}$.

Assays of growth were also carried out in 24-well multi-well tissue culture plates with lids (Falcon Plastics, Div. Becton Dickinson Co., Oxnard, CA). Cells were plated at a density of $\sim 25,000$ per well in DME containing 10\% serum (calf/horse, 2:1). After $24 \mathrm{~h}$ the media were exchanged for DME containing $10 \%$ resin-treated thyroidectomized calf serum $\left(T_{3}, 5 \mathrm{pM}\right)$. After $72 \mathrm{~h}$, media were exchanged for experimental media. These cultures were refed with the respective experimental media after $48 \mathrm{~h}$ and cells were harvested for protein determination after an additional $48 \mathrm{~h}$.

Assays. DNA was determined by the diphenylamine reaction by the method of Giles and Meyers (24) employing calf thymus DNA as the standard. Cell protein was measured by the method of Lowry et al. (25) employing bovine serum albumin as the standard. The concentration of GH was measured by radioimmunoassay employing reagents kindly provided by the Rat Pituitary Hormone Distribution Program of the
National Institutes of Allergy, Digestive Diseases and Kidney, National Institutes of Health (NIH). The method recommended by the NIH was employed, with minor modifications (16). The intraassay coefficient of variation was $6.0 \%$ and the interassay coefficient of variation was $8.8 \%$. In each experiment, all samples from a single experiment were analyzed in the same assay, $T_{3}$ concentration of nonimmune and anti- $T_{3}$ serum was determined by radioimmunoassay (22).

Statistics. Data expressed as the mean \pm SEM. Statistical significance levels were evaluated by Student's $t$ test for unpaired samples or by analysis of variance, where appropriate (26).

\section{Results}

Studies in unconditioned medium. In order to determine whether conditioned medium that contained $0.2 \mathrm{nM} \mathrm{T}_{3}$ also contained growth-promoting activity that was independent of $T_{3}$, it was necessary to remove $T_{3}$ from the medium or decrease the ability of the hormone to enter cells and stimulate cell growth. In the present studies, we changed $T_{3}$ distribution between medium and cells and effected a decrease in steady-state cellular $T_{3}$ concentration by addition of anti- $\mathrm{T}_{3}$ serum to the conditioned medium. Fig. 1 illustrates a representative experiment in which increasing concentrations of rabbit polyclonal anti- $\mathrm{T}_{3}$ serum were titrated against the cellular accumulation of $\left[{ }^{125} \mathrm{I}\right] \mathrm{T}_{3}$. Since $\left.{ }^{[25} \mathrm{I}\right] \mathrm{T}_{3}$ was incubated with GC cells for $3 \mathrm{~h}$ and the $t_{1 / 2}$ of exit

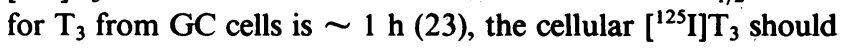
approximate the steady state cellular $T_{3}$. We have previously reported the results of a time course study which showed that the 3-h incubation period is sufficient to attain $90 \%$ equilibration between intracellular and extracellular compartments under similar experimental conditions (23). The present data show that addition of increasing amounts of anti- $\mathrm{T}_{3}$ serum resulted in a progressive decrease in cellular $T_{3}$ to a nadir at between $3 \mu \mathrm{l}$ antiserum $/ \mathrm{ml}$ medium and $5 \mu \mathrm{l}$ antiserum $/ \mathrm{ml}$ medium. In contrast, addition of $5 \mu \mathrm{l}$ nonimmune (normal) rabbit serum $/ \mathrm{ml}$ medium did not affect cellular $\left[{ }^{125} \mathrm{I}\right] \mathrm{T}_{3}$. The decrease in GC cell $\left[{ }^{125} \mathrm{I}\right] \mathrm{T}_{3}$ observed in the presence of anti- $\mathrm{T}_{3}$ serum occurred both in the nuclear and extranuclear cellular compartments. Moreover, this effect of anti- $\mathrm{T}_{3}$ serum, appeared stable for at least 48

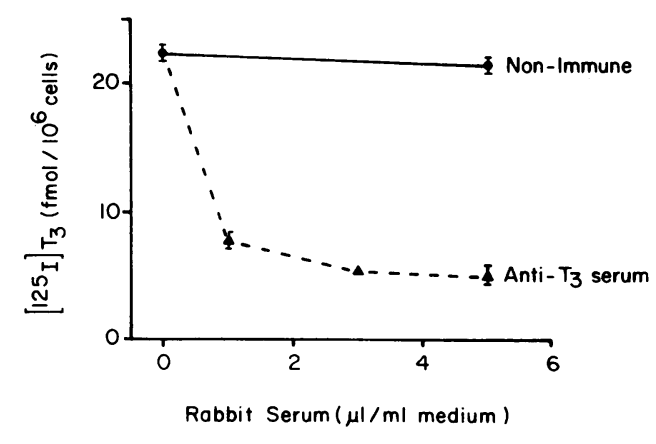

Figure 1. The effect of anti- $\mathrm{T}_{3}$ serum on $\mathrm{T}_{3}$ content of cultured GC cells. The distribution of $\left[{ }^{125} \mathrm{I}\right] \mathrm{T}_{3}$ was determined after $3 \mathrm{~h}$ of incubation in $10 \%$ serum (calf/horse, 2:1)-containing medium with $0.1 \mathrm{nM}$ $\left[{ }^{125} \mathrm{I}\right] \mathrm{T}_{3}$ and either nonimmune rabbit serum or increasing amounts of anti- $T_{3}$ serum. The calculation of medium and cellular $T_{3}$ included the $T_{3}$ content of nonimmune rabbit serum $(1.0 \mathrm{ng} / \mathrm{ml})$ and anti- $T_{3}$ serum $(13.2 \mathrm{ng} / \mathrm{ml})$. Data points represent the mean of three tissue culture dishes. The vertical brackets represent the standard error of the mean. 
Table I. Effect of Anti-T, Serum on Growth of GC Cells Cultured in Either Unconditioned or Conditioned Medium*

\begin{tabular}{|c|c|c|c|}
\hline Medium ${ }^{\ddagger}$ & Experiment 1 & Experiment 2 & Experiment 3 \\
\hline & $\mu g / d i s h$ & $\mu g / d i s h$ & $\mu g / d i s h$ \\
\hline Unconditioned & $12.2 \pm 1.0$ & $15.1 \pm 1.6$ & $21.9 \pm 1.2$ \\
\hline Unconditioned $+\mathrm{T}_{3}$ & $21.2 \pm 0.4$ & $55.1 \pm 4.4$ & $53.8 \pm 3.7$ \\
\hline Unconditioned $+T_{3}+$ anti- $T_{3}$ serum & $9.5 \pm 0.6^{8}$ & $38.9 \pm 2.9^{\prime \prime}$ & $37.3 \pm 5.7^{1}$ \\
\hline Conditioned & $19.7 \pm 2.0$ & $85.1 \pm 9.2$ & $52.8 \pm 2.8$ \\
\hline Conditioned + anti- $T_{3}$ serum & $16.8 \pm 1.1^{* *}$ & $83.8 \pm 5.9^{* *}$ & $57.4 \pm 4.9^{* *}$ \\
\hline
\end{tabular}

\begin{abstract}
* DNA (experiment 1) or protein content (experiments 2 and 3 ) of GC cells grown in tissue culture dishes (experiment 1 ) or multiwells (experiments 2 and 3). Cells were maintained in unconditioned (fresh) or conditioned medium $\left(0.2 \mathrm{nM} \mathrm{T}_{3}\right.$ ) for $72 \mathrm{~h}$ (experiment 2 ) or $96 \mathrm{~h}$ (experiments 1 and 3) before they were collected for determinations of DNA or protein. The designated culture received anti-T 3 serum (5 $\mu \mathrm{l} / \mathrm{ml})$; other cultures received $5 \mu \mathrm{l} / \mathrm{ml}$ nonimmune serum. At the initiation of treatment with experimental media, the DNA content was $4.9 \pm 0.2 \mu \mathrm{g} /$ dish in experiment 1 and the protein content was $6.9 \pm 0.4$ and $11.0 \pm 0.7 \mu \mathrm{g} /$ well in experiments 2 and 3 , respectively. Data are expressed as mean $\pm S E M$. ${ }^{\ddagger} T_{3}$ concentration, $0.2 \mathrm{nM}$. $P<0.001$ in comparison to unconditioned medium $+\mathrm{T}_{3}$. " $P<0.025$ in comparison to unconditioned medium $+\mathrm{T}_{3}$. $' P<0.01$ in comparison to unconditioned medium in $\mathrm{T}_{3}$. ${ }^{* *}$ Not significantly different $(P>0.05)$ from conditioned medium.
\end{abstract}

h. When the distribution of $0.2 \mathrm{nM}\left[{ }^{125} \mathrm{I}\right] \mathrm{T}_{3}$ was determined 48 $h$ after addition of anti- $T_{3}$ serum, the nuclear and extranuclear $\left[{ }^{125} \mathrm{I}\right] \mathrm{T}_{3}$ was $9.5 \pm 0.3$ and $6.6 \pm 0.1 \mathrm{fmol} / 10^{6}$ cells, respectively, in the presence of nonimmune serum. Cellular $T_{3}$ decreased to $2.7 \pm 0.3$ and $1.8 \pm 0.1 \mathrm{fmol} / 10^{6}$ cells, respectively, in the presence of anti- $\mathrm{T}_{3}$ serum. These findings together suggest that addition of a potent anti- $T_{3}$ serum to the medium effected a significant and sustained reduction in cellular $T_{3}$.

Evidence that depletion of cellular $T_{3}$ by anti- $T_{3}$ serum resulted in decreased hormonal activity is shown in Table I. Significant stimulation of GC cell growth measured by an increment in DNA synthesis (experiment 1) or cell protein (experiments 2 and 3) was apparent for cultures maintained in fresh, unconditioned medium that was supplemented with $0.2 \mathrm{nM} \mathrm{T}_{3}$. Addition of anti- $\mathrm{T}_{3}$ serum significantly attenuated the increase in DNA or protein induced by $T_{3}$. In the presence of anti- $T_{3}$ serum, the $T_{3}$-stimulated increase in DNA was prevented in experiment 1 and the increase in cell protein was inhibited by 40 and $54 \%$, respectively, in experiments 2 and 3 . These studies suggest that addition of sufficient anti- $\mathrm{T}_{3}$ serum to fresh unconditioned medium to decrease $G C$ cell $T_{3}$ concentration results in a significant decrease in $T_{3}$-induced stimulation of cell growth.

The relationship between magnitude of the depletion of cellular $T_{3}$ (Fig. 1) and decrease in cell growth (Table $I$ ) in the presence of anti- $T_{3}$ serum can be appreciated by analysis of $T_{3}$ dose-response curves for cell growth. Fig. 2 illustrates a repre-

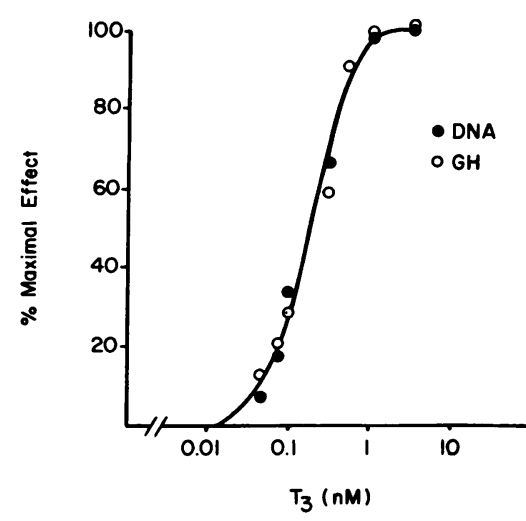

Figure 2. $\mathrm{T}_{3}$ dose-response for cell growth and $\mathrm{GH}$ secretion. The primary data for the $T_{3}$ dose-response curves for cell growth (DNA) and GH secretion has been published in a different form previously by our laboratory (18). The onehalf maximal effect for both of these parameters occurred at $0.2 \mathrm{nM} \mathrm{T}_{3}$ (range, $0.16-0.25 \mathrm{nM}$ $\mathrm{T}_{3}$ ). sentative dose-response curve for cell growth. The one-half maximal effect occurred at $0.2 \mathrm{nM} \mathrm{T}_{3}$ (range, $0.16-0.25 \mathrm{nM}$ ). Since the anti- $T_{3}$ sera employed in these experiments effected a $50-70 \%$ decrease in cellular $T_{3}$, examination of the dose-response curve predicts a $40-70 \%$ decrease in cell growth. These estimates are in reasonable accord with the data listed in Table I. The mean percentage decrease in $T_{3}$ effect on cell growth resulting from addition of anti- $\mathrm{T}_{3}$ serum to unconditioned medium supplemented with $0.2 \mathrm{nM} \mathrm{T}_{3}$ was $100,40.1$, and $51.7 \%$ in experiments 1,2 , and 3 , respectively.

Two experiments were then carried out to determine whether the attenuation of cell growth observed in cultures with anti- $\mathrm{T}_{3}$ serum resulted from binding of $T_{3}$ by anti- $T_{3}$ serum and a decrease in cellular $T_{3}$. Cell growth of cultures maintained in the presence of anti- $T_{3}$ serum was determined after cellular $T_{3}$ was restored to control values by addition of $\mathrm{T}_{3}$ (Fig. 3). Preliminary studies of $\mathrm{T}_{3}$ distribution were carried out as described for Fig. 1. The anti- $T_{3}$ serum employed for these experiments decreased cellular $T_{3}$ from $22.0 \pm 0.2 \mathrm{fmol}$ per $10^{6}$ cells to $10.4 \pm 0.8 \mathrm{fmol}$ per $10^{6}$ cells. When $1.0 \mathrm{nM} \mathrm{T}_{3}$ was added in the presence of anti- $T_{3}$ serum, cellular $T_{3}$ was restored to $24.7 \pm 0.5 \mathrm{fmol}$ per $10^{6}$ cells. The data in Fig. 3 show changes in mean protein content per well that reasonably parallel the changes in cellular $T_{3}$ under these incubation conditions. The addition of anti- $\mathrm{T}_{3}$ serum to cells cultured with $0.2 \mathrm{nM} \mathrm{T}_{3}$ decreased the mean increment in cell protein per well by 39.9 and $35.4 \%$ in experiments $A$ and B, respectively. However, when $1.0 \mathrm{nM} \mathrm{T}_{3}$ was added in the presence of anti- $T_{3}$ serum, the increment in cell protein per well was restored to 92 and $108 \%$ of control values. The finding that restoration of cellular $T_{3}$ to control concentrations by addition of $1.0 \mathrm{nM} \mathrm{T}_{3}$ reversed the decrease in cell growth produced by anti- $T_{3}$ serum suggests that the anti- $T_{3}$ serum exerts its effects principally by binding $T_{3}$ and decreasing cellular $T_{3}$ content.

Studies in conditioned medium. In contrast to these findings for unconditioned medium, addition of anti- $\mathrm{T}_{3}$ serum did not appear to decrease the induction of cell growth by medium that also contained $0.2 \mathrm{nM} \mathrm{T}_{3}$ but which was conditioned for $24 \mathrm{~h}$ by GC cells (Table I). In experiments 1 and 3, cultures maintained in conditioned medium exhibited a growth response that was comparable to that of unconditioned medium containing $T_{3}$ and in experiment 2 , the growth stimulation caused by con- 

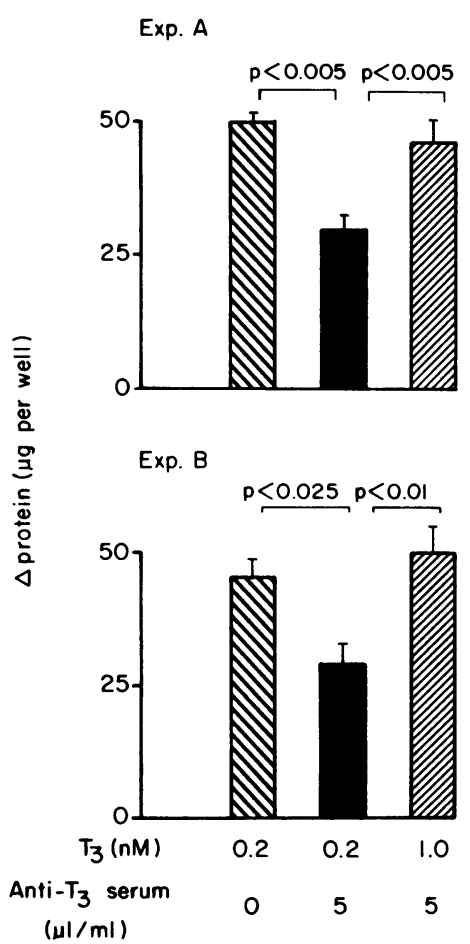

maintained without $T_{3}$ supplementation was $46.1 \pm 0.9 \mu \mathrm{g}$ per well and $50.3 \pm 1.2 \mu \mathrm{g} /$ well. After addition of $0.2 \mathrm{nM} \mathrm{T}_{3}$, these values increased to $96.0 \pm 2.1 \mu \mathrm{g} /$ well and $95.8 \pm 4.3 \mu \mathrm{g} /$ well.

ditioned medium significantly exceeded that of unconditioned medium containing $T_{3}$. In all three experiments, however, addition of anti- $T_{3}$ serum to the conditioned medium did not significantly influence the induction of growth by that medium. Since anti- $T_{3}$ serum significantly decreased $T_{3}$ action when added to fresh, unconditioned medium, these findings suggest that conditioned medium may contain growth-promoting activity that is independent of the presence of $T_{3}$.

To establish that addition of anti- $T_{3}$ serum to conditioned medium reduced the cellular action of $T_{3}$ at the same time that growth stimulation was maintained, we compared the simultaneous effects of anti- $\mathrm{T}_{3}$ serum on induction of both growth and $\mathrm{GH}$ for cultures maintained in unconditioned and conditioned medium (Figs. 4 and 5). Since $T_{3}$ specifically induces $G H$ production in GC cells $(17,27-30)$, measurements of $\mathrm{GH}$ concentration in medium by radioimmunoassay provide a convenient and specific bioassay for $\mathrm{T}_{3}$ action in these cells. Moreover, the virtually identical $T_{3}$ dose-response curves for induction of both growth and $\mathrm{GH}$ as illustrated in Fig. 2 facilitate quantitative comparisons between these biological parameters. Mean GH production (nanograms per hour per $10^{6}$ cells) of cultures maintained in $\mathrm{T}_{3}$-depleted ( $5 \mathrm{pM}$ ) unconditioned medium was $0.08 \pm 0.01$ and $0.07 \pm 0.01$ in experiments 4 and 5 , respectively. Addition of $0.2 \mathrm{nM} \mathrm{T}_{3}$ to fresh, unconditioned medium resulted in an increase in $\mathrm{GH}$ production to $0.99 \pm 0.02$ and $0.91 \pm 0.05$ $\mathrm{ng} / \mathrm{h}$ per $10^{6}$ cells, respectively. As shown in the left panels of Fig. 4, addition of anti- $\mathrm{T}_{3}$ serum decreased the induction of $\mathrm{GH}$ by $\mathrm{T}_{3}$ by $\sim 50 \%$ in each experiment.

As shown in the right panels of Fig. 4, conditioned medium that contained $0.2 \mathrm{nM} \mathrm{T}_{3}$ also stimulated $\mathrm{GH}$ production. In

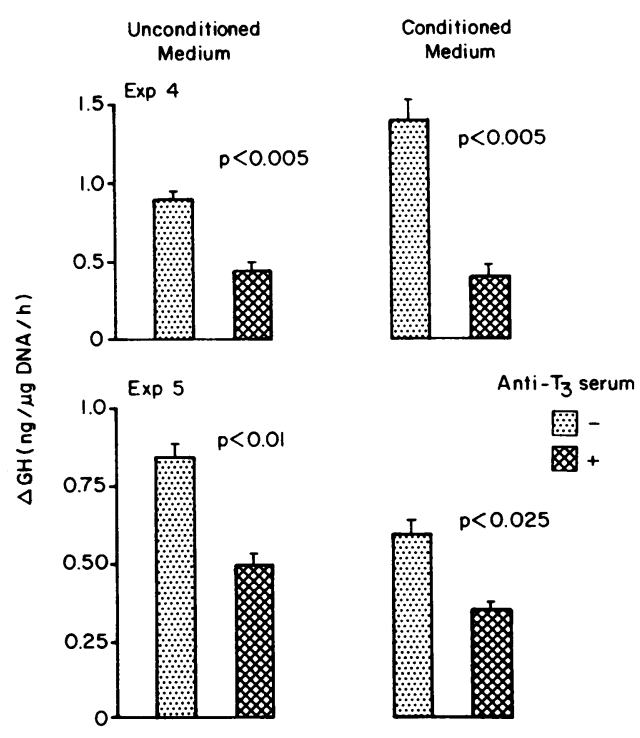

Figure 4. Effect of anti- $\mathrm{T}_{3}$ serum on induction of growth hormone by unconditioned or conditioned medium. Cultures of GC cells were maintained in either unconditioned medium containing $10 \%$ resintreated thyroidectomized calf serum, unconditioned medium containing $10 \%$ resin-treated thyroidectomized calf serum, supplemented with $\mathrm{T}_{3}(0.2 \mathrm{nM})$ and either anti- $\mathrm{T}_{3}$ serum (cross-hatched bars) or nonimmune rabbit serum $(5 \mu \mathrm{l} / \mathrm{ml}$ medium), or conditioned medium $(0.2$ $n M T_{3}$ ) containing either anti- $\mathrm{T}_{3}$ serum (cross-hatched bars) or nonimmune rabbit serum, $5 \mu \mathrm{l} / \mathrm{ml}$ medium (stippled bars) for $120 \mathrm{~h}$. Media from the last $48 \mathrm{~h}$ (experiment 4 ) or $72 \mathrm{~h}$ (experiment 5) of incubation in experimental media were retained for determination of $\mathrm{GH}$. The height of the bars indicates the mean increment in medium GH in comparison to cells grown in unconditioned, $\mathrm{T}_{3}$-depleted medium. The vertical brackets represent the standard error of the mean. The concentration of $\mathrm{GH}$ in experimental dishes that contained conditioned medium was corrected for the GH initially present in the conditioned media.

comparison to the control $\mathrm{T}_{3}$-depleted cultures, the induction of $\mathrm{GH}$ by conditioned medium was 14-fold in experiment 4 and 7-fold in experiment 5 . Similar to our findings for unconditioned medium (Fig. 4, left panel), addition of anti- $\mathrm{T}_{3}$ serum to conditioned medium resulted in a significant decrease in the induction of $\mathrm{GH}$ (Fig. 4, right panels). In the presence of anti- $\mathrm{T}_{3}$ serum, GH production was attenuated by $74 \%$ in experiment 4 and $38 \%$ in experiment 5 . These studies suggest that addition of anti- $T_{3}$ serum effected a comparable decrease in $T_{3}$ action as assessed by GH production for cultures in unconditioned and conditioned medium.

Different results were obtained when DNA was determined in the same cultures that were used for measurement of $\mathrm{GH}$ production (Fig. 5). Mean DNA of cultures in fresh, $T_{3}$-depleted unconditioned medium was $11.5 \pm 0.3 \mu \mathrm{g} /$ dish and $8.5 \pm 0.1 \mu \mathrm{g} /$ dish in experiments 4 and 5 , respectively. Treatment with 0.2 $\mathrm{nM} \mathrm{T} \mathrm{T}_{3}$ resulted in 3.0-fold increase in DNA in experiment 4 and 3.8-fold increase in DNA in experiment 5. As shown in Fig. 5 (left panels), addition of anti- $\mathrm{T}_{3}$ serum to unconditioned medium significantly decreased the $\mathrm{T}_{3}$-induced augmentation of cell growth. The mean decrease was $46.7 \%$ in experiment 4 and $36.5 \%$ in experiment 5 . The increment in mean DNA per dish for cultures maintained in conditioned medium was 13.4 and $19.1 \%$ greater $(P<0.05)$ than that of cultures in unconditioned 


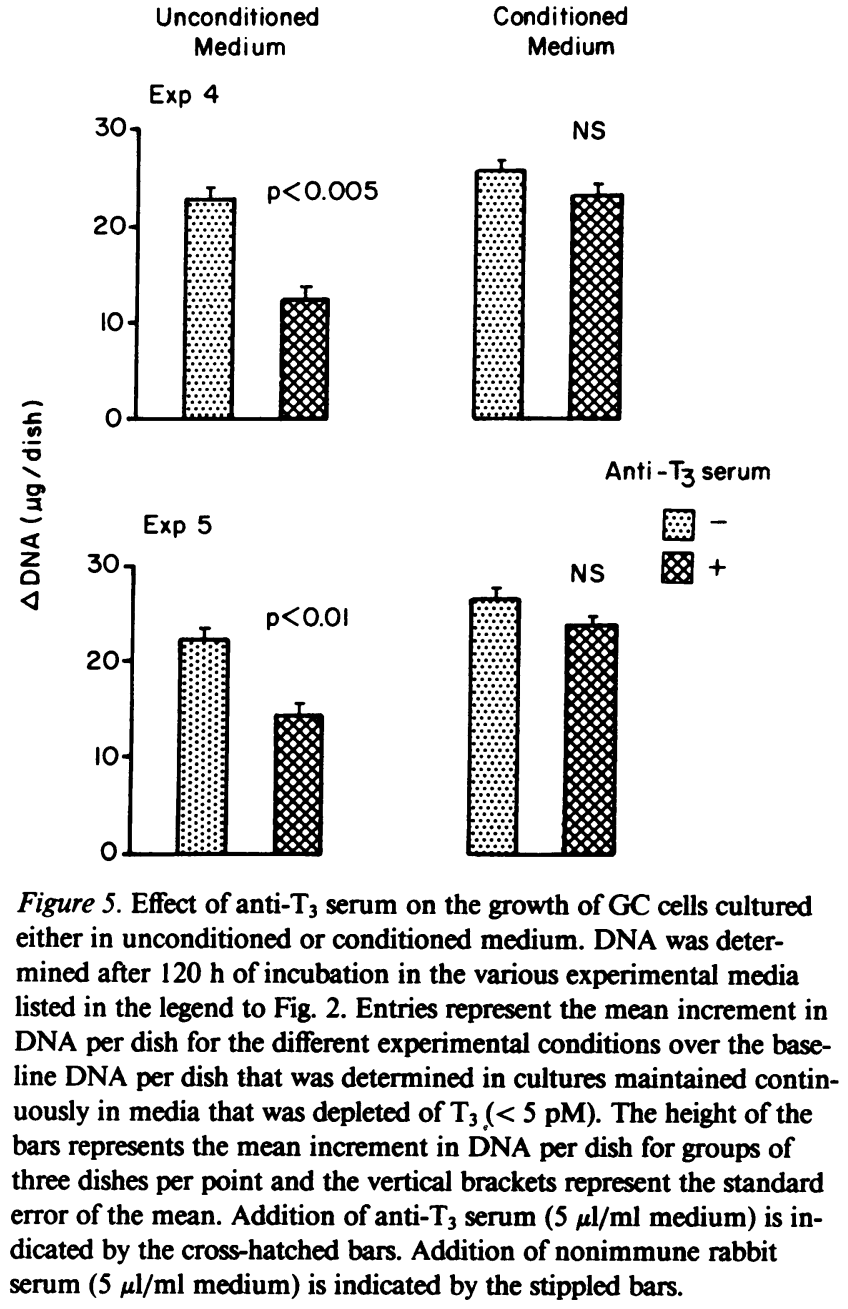

medium for experiments 4 and 5 , respectively. Although addition of anti- $\mathrm{T}_{3}$ serum caused a small decrease in DNA in these cultures, the change was not significant statistically. Moreover, the increment in DNA of cultures maintained in conditioned medium supplemented with anti- $\mathrm{T}_{3}$ serum remained equivalent to that of cultures in fresh, unconditioned medium. These studies suggest that conditioned medium contained significant growthpromoting activity even in the presence of anti- $\mathrm{T}_{3}$ serum.

To determine whether the presence of $T_{3}$ during the conditioning of the medium was required for the growth-promoting activity observed in conditioned medium, we determined the growth-promoting activity of medium conditioned by GC cells that were depleted of $T_{3}$. The cell number of the producing cells was $\sim 8.0 \times 10^{6}$ per flask at the start of collections, equivalent to the cell number of all other preparations of conditioned medium in this investigation. Similar to the above results, addition of $0.2 \mathrm{nM} \mathrm{T}_{3}$ to $\mathrm{T}_{3}$-depleted assay cultures resulted in a significant increase in mean DNA per dish (Table II). However, in contrast to the results employing conditioned medium from cells grown in the presence of $T_{3}$, medium that was conditioned by $T_{3}$-depleted cultures did not seem to contain significant growth promoting activity. This finding suggests that the presence of $T_{3}$ during conditioning of the medium is required to demonstrate the growth-promoting activity.
Table II. Effect of Conditioned Medium from GC Cells Maintained in $T_{5}$-depleted Conditions on GC Cell Growth*

\begin{tabular}{llll}
\hline & Medium & & \\
\cline { 2 - 4 } $\begin{array}{l}\text { Experiment } \\
\text { No. }\end{array}$ & Unconditioned & $\begin{array}{l}\text { Unconditioned } \\
+0.2 \mathrm{nM} \mathrm{T}_{3}\end{array}$ & Conditioned \\
\hline & $\mu g / D N A$ per dish & $\mu g / D N A$ per dish & $\mu g / D N A$ per dish \\
1 & $7.5 \pm 1.0$ & $26.3 \pm 2.3^{\ddagger}$ & $10.7 \pm 0.6^{\S}$ \\
2 & $24.7 \pm 0.2$ & $35.6 \pm 1.4^{41}$ & $26.8 \pm 1.3^{\S}$ \\
\hline
\end{tabular}

* Entries are mean \pm SEM for groups of three culture dishes. GC cells were maintained in unconditioned (fresh) medium in the presence or absence of $0.2 \mathrm{nM} \mathrm{T}_{3}$ or medium conditioned by $T_{3}$-depleted $\mathrm{GC}$ cells for $5 \mathrm{~d}$ before they were collected for DNA determination.

${ }^{\ddagger} P<0.001$ in comparison to unconditioned medium.

${ }^{8}$ Not significantly different $(P>0.05)$ from unconditioned medium.

" $P<0.01$ in comparison to unconditioned medium.

The present findings suggest that $\mathrm{T}_{3}$-containing conditioned medium also contained growth-promoting activity that was independent of $T_{3}$. Since the conditioned medium contained serum, we could not distinguish between two possible mechanisms for this effect: (a) that GC cells secrete a mitogen that stimulates GC cell growth and $(b)$, that the presence of the cells and $T_{3}$ alter a mitogen already present in the thyroidectomized calf serum and enable it to stimulate cell growth. To help distinguish between these possibilities, we measured the growthpromoting activity of serum-free conditioned medium. Similar to the experiments described above, cells were cultured in $10 \%$ serum-containing medium until cell number was $7.0 \times 10^{6}$ to $9.0 \times 10^{6}$ per flask. The medium was then removed and the cells were rinsed twice with serum-free medium. Serum-free conditioned medium was then collected after additional $24 \mathrm{~h}$. Table III shows the results of four experiments. Similar to studies described in Table I and Figs. 4 and 5, incubation with unconditioned medium containing $0.2 \mathrm{nM} \mathrm{T}_{3}$ or conditioned medium with added anti- $\mathrm{T}_{3}$ serum resulted in a similar and significant increase in cell growth. The data also show that medium conditioned in the absence of serum resulted in a significant increase in cell growth $(P<0.005-P<0.001)$. The mean increment in cell growth resulting from incubation with serum-free conditioned medium was $34 \%$ of the increment in growth produced by unconditioned medium $\left.(0.2 \mathrm{nM} \mathrm{T})_{3}\right)$ or serum-containing conditioned medium in the presence of anti- $\mathrm{T}_{3}$ serum. Similar findings were obtained when the serum-free medium was conditioned in the presence or absence of $0.1 \mathrm{nM} \mathrm{T}_{3}$. In the latter experiment growth stimulation was tested after addition of anti$\mathrm{T}_{3}$ serum.

\section{Discussion}

Our present findings extend earlier observations from our laboratory using a cultured somatotrophic cell line $(\mathrm{GC})$ as a model system to examine the effects of thyroid hormone on cell growth. In those studies, we reported that $T_{3}$ accelerated the rate of cell growth by shortening the G1 period from a mean of 79.4 \pm 2.2 $h$ to $10.0 \pm 0.05 h(15)$. This action of $T_{3}$ appeared to be restricted to the first $6 \mathrm{~h}$ of the G1 period, had a dose-response curve and iodothyronine analogue specificity that suggested mediation by 
Table III. Effect of $T_{3}$-depleted Serum-free Conditioned Medium on GC Cell Growth*

\begin{tabular}{|c|c|c|c|c|}
\hline Medium & Exp. 1 & Exp. 2 & Exp. 3 & Exp. 4 \\
\hline & $\mu g /$ well & $\mu g /$ well & $\mu g /$ well & $\mu g /$ well \\
\hline Unconditioned & $17.7 \pm 1.4$ & $19.7 \pm 2.1$ & $19.7 \pm 2.1$ & $22.5 \pm 1.6$ \\
\hline Unconditioned $+T_{3}$ & $79.4 \pm 5.8^{\ddagger}$ & $62.6 \pm 2.7^{\ddagger}$ & $65.2 \pm 0.9^{\ddagger}$ & $67.3 \pm 3.0^{\ddagger}$ \\
\hline Conditioned + anti- $T_{3}$ serum & $85.3 \pm 2.0^{\ddagger}$ & $60.7 \pm 1.8^{\ddagger}$ & $79.2 \pm 4.1^{\ddagger}$ & $\mathrm{ND}^{\S}$ \\
\hline Serum-free conditioned & $34.2 \pm 1.5^{\prime \prime}$ & $38.6 \pm 2.3^{\ddagger}$ & $37.9 \pm 1.1^{\ddagger}$ & $34.2 \pm 1.1^{11}$ \\
\hline $\mathbf{F}$ & 105.8 & 58.5 & 101.6 & 130.3 \\
\hline$P<$ & 0.001 & 0.001 & 0.001 & 0.001 \\
\hline
\end{tabular}

* Protein content of GC cells grown in multiwells (micrograms per well). Cells were maintained in unconditioned medium with or without 0.2 $\mathrm{mM} \mathrm{T}_{3}$, conditioned $\left(0.2 \mathrm{nM} \mathrm{T}_{3}\right)$ medium, or in serum-free conditioned medium for 3-5 d before they were collected for protein determination. The designated cultures received anti- $\mathrm{T}_{3}$ serum $(5 \mu \mathrm{l} / \mathrm{ml})$; all other cultures received $5 \mu \mathrm{l} / \mathrm{ml} \mathrm{nonimmune} \mathrm{serum.} \mathrm{Data} \mathrm{expressed} \mathrm{as} \mathrm{mean} \pm S E M$. $F$, variance ratio. ${ }^{\ddagger} P<0.001$ in comparison to unconditioned medium. ${ }^{8} \mathrm{ND}$, not determined. $\quad P<0.005$ in comparison to unconditioned medium.

the nuclear iodothyronine receptor, and required protein synthesis $(19,20)$. Our findings thus suggested that $T_{3}$ might induce growth by means of induction of a specific growth promoting peptide. We now report that conditioned medium from GC cells cultured in the presence of physiologic concentrations of $\mathrm{T}_{3}(0.2$ $n M)$ stimulates growth of $T_{3}$-depleted $G C$ cells cultures even in the presence of anti- $\mathrm{T}_{3}$ serum, which was added to decrease cellular $T_{3}$. In contrast, medium that was conditioned by a similar number of GC cells maintained in the absence of $T_{3}$ appeared devoid of this growth-promoting activity. The presence of $T_{3}$ during conditioning of the medium thus appeared to be required for the presence of the growth-promoting activity. These findings suggested that $T_{3}$ stimulates growth of asynchronous GC cell cultures, at least in part, by promoting secretion into the medium of an autocrine growth factor. We cannot at this time, determine whether this autocrine growth-promoting mechanism is responsible for the growth-stimulating action of $T_{3}$ during the first $6 \mathrm{~h}$ of the $\mathrm{G} 1$ period. Such studies will require analysis of conditioned medium from synchronized cultures of GC cells.

Although we may speculate that $T_{3}$ primarily induced the secretion into the medium of an autocrine growth stimulator, our present studies do not address this issue directly. From previous reports from our laboratory (15), we may assume that the GC cells employed for conditioning the medium were doubling every $24.6 \pm 0.6 \mathrm{~h}$ when $\mathrm{T}_{3}$ was maintained at $0.2 \mathrm{nM}$ and at every $112.0 \pm 0.2 \mathrm{~h}$ when $\mathrm{T}_{3}$ was maintained at $<10 \mathrm{pM}$. Thus, the growth-promoting activity observed in the medium from cultures growing in the presence of $T_{3}$ might be a function of rapid cell growth rather than a primary response to $T_{3}$. It is possible that $T_{3}$ may stimulate growth by a separate mechanism and that growing cells produce the growth factor described in this report. Since the rate of GC cell growth depends on $T_{3}(15$, 18 ), experimental protocols to distinguish between these possibilities have not yet been developed. Resolution of this interesting question will probably require purification of the growth-promoting activity and appropriate biochemical studies.

Since growth-promoting activity of conditioned medium from cultures in $T_{3}$-containing medium could be due to the $T_{3}$ in the medium or to an induced growth factor, it was necessary to develop a strategy either to remove the $T_{3}$ or decrease the cellular $T_{3}$ content to test for the presence of growth factor activity. Several approaches were taken to accomplish this goal.
In several studies, addition of Dowex $1 \times 400$ anion exchange resin (21) to conditioned medium effectively removed $T_{3}$. Even after removal of the resin by centrifugation and extensive dialysis against serum-free unconditioned medium, however, the resulting medium appeared toxic to control cultures. $T_{3}$ was also removed effectively ( $90 \%$ in $24 \mathrm{~h}$ ) when conditioned medium was dialyzed against unconditioned medium containing the same resin. Although some studies with this medium did suggest the presence of growth-promoting activity, results were not consistent because of intermittent cell toxicity. These experiences led to the direct addition of anti- $\mathrm{T}_{3}$ serum to conditioned medium in order to decrease the cellular concentration of $T_{3}$. Cell toxicity, in the form of detachment from the plate or cell death was not observed in incubations with anti- $T_{3}$ serum. Addition of anti$T_{3}$ serum as employed in these studies resulted in a $50-70 \%$ decrease in GC cell $\mathrm{T}_{3}$ concentration, and, when added to fresh unconditioned medium, an $\sim 40-70 \%$ decrease in induction of cell growth and $\mathrm{GH}$ production by $\mathrm{T}_{3}$. Our studies also suggest that these effects of anti- $T_{3}$ serum resulted specifically from depletion of cellular $T_{3}$. When cellular $T_{3}$ pools were restored to normal values by addition of $\mathrm{T}_{3}(1.0 \mathrm{nM})$, cell growth was also restored to control rates. Addition of anti- $T_{3}$ serum to conditioned medium also attenuated $\mathrm{GH}$ production suggesting a similar decrease in cellular $T_{3}$ levels to the studies in unconditioned medium. However, the finding that growth induction was not significantly altered when anti- $T_{3}$ serum was added to conditioned medium suggested the presence in conditioned medium of growth-promoting activity that was not related to cellu$\operatorname{lar} \mathrm{T}_{3}$.

Although our studies show that conditioned medium from $\mathrm{T}_{3}$-treated GC cells contained growth-promoting activity, they have not yet shed light on the chemical nature of the activity. In preliminary studies, we have demonstrated that the growthpromoting activity is retained after dialysis using membranes with a 3,500-D pore size. Thus, the activity seems to be a macromolecule, probably, by analogy with other growth factors, a protein. It is of interest that after these results were presented (30a), Hinkle (31) reported that $\mathrm{GH}_{4} \mathrm{C}_{1}$ cells also seemed to secrete an autocrine growth factor in the presence of $T_{3}$. In those studies, the growth-promoting activity appeared to have a molecular weight $\geq 50,000 \mathrm{D}$ suggesting that it was a protein or protein-bound. Since purification of the growth factor activity 
would be facilitated by the absence of the serum proteins in the medium, we have collected serum free conditioned medium that contains $\mathrm{T}_{3}$ and tested it for growth-promoting activity. Such medium exhibited reproducible growth induction, $\sim 34 \%$ that of serum-containing conditioned medium. The presence of growth-promoting activity in serum-free conditioned medium suggests that the cells are secreting a mitogen under the influence of $\mathrm{T}_{3}$. Since growth induction by serum-free conditioned medium is significantly less than serum-containing conditioned medium, it is also possible that some component in the calf serum is responsible for the full biological activity of the growthpromoting substance. Additionally, the cells under the influence of $T_{3}$ may alter a mitogen present in calf serum which is responsible, in part, for some of the growth promoting activity of serum-containing conditioned medium. The further characterization of the $\mathrm{T}_{3}$-induced growth-promoting activity currently in progress, is required to distinguish between these possible mechanisms.

Published reports suggest that thyroid hormones may have a role in the regulation of several growth factors. Marek et al. (32) reported that somatomedin activity was significantly increased in hyperthyroid patients and decreased in patients with hypothyroidism. Decreased somatomedin-C concentration was also reported in 11 of 12 hypothyroid patients by Chernausek et al. (33); thyroid hormone therapy resulted in fourfold increase in somatomedin- $C$ concentration in these patients (33). These studies in human subjects suggest that thyroid hormones may regulate somatomedin- $\mathrm{C}$ but do not distinguish whether the regulation is a direct effect of thyroid hormone or is mediated by GH. Studies of somatomedin regulation in cultured human fibroblasts provide further insight into these issues. Clemmons et al. (34) showed that thyroxine did not augment somatomedin$\mathrm{C}$ secretion in cultured quiescent fibroblasts. However, when quiescent fibroblasts were stimulated to enter the cell cycle by addition of platelet-derived growth factor, addition of $\mathrm{T}_{4}$ did stimulate somatomedin-C (35). Lastly, Binoux et al. (36) reported that short-term primary cultures of dissociated hypothalamus cells secrete insulinlike growth factor (IGF) into the medium and that addition of $T_{3}$ augmented the medium IGF concentration in a dose-dependent manner. These studies together indicate that under some experimental conditions, $T_{3}$ may stimulate secretion of IGF by cultured cells and may also augment somatomedin-C levels in human subjects.

Other studies show that thyroid hormones may regulate epidermal growth factor (EGF) and nerve growth factor (NGF) in neonatal and adult mice. EGF and NGF are present in high concentration in the submandibular gland (SMG) of the mouse $(37,38)$. Administration of thyroid hormone increases these levels in adult mice (39-42) and precociously augments the concentration of both growth factors in neonatal submandibular glands (43). The thyroid hormone-induced increase in SMG EGF is paralleled by an increase in EGF mRNA activity (44). Somewhat conflicting data have been reported for NGF regulation in mouse L-cells. Siminoski et al. (45) showed that very high concentrations of $\mathrm{T}_{3}\left(10^{-5} \mathrm{M}\right)$ decreased NGF concentration in the medium of mouse L-929 fibroblasts. Smaller concentrations of $T_{3}$ did not appear to influence NGF concentration. However, Wion et al. (46) recently reported that $10^{-7} \mathrm{M} \mathrm{T}_{3}$ or $\mathrm{T}_{4}$ augmented beta-NGF mRNA in mouse $L$ cells.

If subsequent studies demonstrate that the growth-promoting activity induced by $T_{3}$ in medium conditioned by GC cells is one of the known growth factors or a unique protein, this thyroidal effect on growth would be analogous to the autocrine growth induction by other hormones in different tissues. For example, 17 B-estradiol appears to induce epidermal growth factor-related polypeptides in MCF-7 human breast cancer cells, which act in an autostimulatory manner (47) as well as a 52,000D glycoprotein that also seems to induce growth in an autocrine fashion (48).

In other studies, conditioned medium from prolactin-treated tumors stimulates colony formation in soft agar of $n$-nitrosomethylurea-induced mammary cancer of rats (49). Other cells appear to regulate their growth, in part, by production of autocrine growth factors. Such is the case for IGF I in smooth muscle cells (50), platelet-derived growth factor in the osteosarcoma cell line, U-2 OS (51), transforming growth factor B in chemically transformed fibroblasts $(52,53)$, and interleukin 2 in $T$ lymphocytes $(54,55)$. Several of the above growth factors influence growth of different tissues. Since $T_{3}$ may regulate growth of many diverse cells $(1-11,13-15)$, a common mechanism employing production of a growth factor that regulates growth in an autocrine fashion may underly this hormonal action.

\section{Acknowledgments}

The authors thank Denise Duchemin and Christine Frawley for the preparation of this manuscript.

This work was supported by National Institutes of Health grants CA-16463-12 and CA-24604-08.

\section{References}

1. Leblond, C. P., and R. Carriere. 1955. The effect of growth hormone and thyroxine on the mitotic rate of the intestinal mucosa of the rat. Endocrinology. 56:261-266.

2. Masterson, E., H. F. Edelhauser, and D. L. Van Horn. 1975. Development of corneal transparency in embryonic chick: Influence of exogenous thyroxine and thiouracil on structure, water and electrolyte content. Dev. Biol. 43:233-239.

3. Hoffman, C. W., and J. N. Dent. 1977. Hormonal regulation of cellular proliferation in the epidermis of the red-spotted newt. Gen. Comp. Endocrinol. 32:522-530.

4. Beach, D. H., and M. Jacobson. 1979. Influence of thyroxine on cell proliferation in the retina of the clawed frog at different ages. $J$. Comp. Neurol. 183:615-624.

5. Wright, M. L., E. M. Sicbaldi, K. M. Loveridge, P. A. Pike, and M. A. Majerowski. 1981. Cell population kinetics in tadpole limb epidermis during thyroxine-induced, spontaneous, and prolactin-inhibited metamorphosis. Gen. Comp. Endocrinol. 43:451-461.

6. Short, J., R. Wedmore, L. Kibert, and R. Zemel. 1980. Triiodothyronine: on its role as a specific hepatomitogen. Cytobios. 28:165177.

7. Kumegawa, M., E. Ikeda, S. Hosoda, and T. Takuma. 1980. In vitro effects of thyroxine and insulin on myoblasts from chick embryo skeletal muscle. Dev. Biol. 79:493-499.

8. Lauder, J. M. 1977. The effects of early hypo- and hyperthyroidism on the development of rat cerebellar cortex. III Kinetics of cell proliferation in the external granular layer. Brain Res. 126:31-51.

9. Patel, A. J., P. D. Lewis, R. Balazs, P. Bailey, and M. Lai. 1979. Effects of thyroxine on postnatal cell acquisition in the rat brain. Brain Res. 172:57-72.

10. Dainat, J., and A. Rebiere. 1980. In vivo action of a single injection of thyroxine on the cerebellar protein synthesis and cellular multipli- 
cations, in normal and hypothyroid young rats. Acta Neurol. Scand. 61: 65-77.

11. Nunez, J. 1984. Effects of thyroid hormone during brain differentiation. Mol. Cell Endocrinol. 37:125-132.

12. Surks, M. I., and C. R. DeFesi. 1977. Determination of the absolute cell number of each cell type in the anterior pituitary of euthyroid and hypothyroid rats. Endocrinology. 101:946-958.

13. Astier, H. S., C. R. DeFesi, and M. I. Surks. 1980. Kinetics of deoxyribonucleic acid synthesis and replication of thyrotrophs and somatotrophs during development of hypothyroidism and L-triiodothyronine treatment of hypothyroid rats. Endocrinology. 106:1537-1548.

14. DeFesi, C. R., H. S. Astier, and M. I. Surks. 1979. Kinetics of thyrotrophs and somatotrophs during development of hypothyroidism and L-triiodothyronine treatment of hypothyroid rats. Endocrinology. 104:1172-1180.

15. DeFesi, C. R., and M. I. Surks. 1981. 3,5,3'-Triiodo-thyronine effects on the growth rate and cell cycle stages of cultured GC cells. Endocrinology. 108:259-267.

16. Surks, M. I., and M. H. Kumara-Siri. 1984. Increase in nuclear thyroid and glucocorticoid receptors and growth hormone production during the DNA synthesis phase of the cell growth cycle. Endocrinology. 114:873-879.

17. Kumara-Siri, M. H., and M. I. Surks. 1985. Regulation of growth hormone mRNA synthesis by 3,5,3'-triiodo-L-thyronine in cultured growth hormone-producing rat pituitary tumor cells $(\mathrm{GC})$ cells. Dissociation between nuclear iodothyronine receptor concentration and growth hormone mRNA synthesis in (S) phase of the cell cycle. J. Biol. Chem. 260:14,529-14,537.

18. Gingrich, S. A., P. J. Smith, L. E. Shapiro, and M. I. Surks. 1985. Diphenylhydantoin (DPH) attenuates thyroid hormone action in cultured GC cells. Endocrinology. 116:2306-2313.

19. DeFesi, C. R., E. C. Fels, and M. I. Surks. 1983. T3 stimulates growth of cultured GC cells by action early in the G1 period. Endocrinology. 114:293-295.

20. DeFesi, C. R., E. C. Fels, and M. I. Surks. 1985. L-triiodothyronine (T3) stimulates growth of cultured GC cells by action early in the $G 1$ period. Evidence for mediation by the nuclear T3 receptor. Endocrinology. 116:2062-2069.

21. Samuels, H. H., F. Stanley, and J. Casanova. 1979. Depletion of L-3,5,3'-triiodothyronine and L-thyroxine in euthyroid calf serum for use in cell culture studies of the action of thyroid hormone. Endocrinology. 105:80-85.

22. Surks, M. I., A. R. Schadlow, and J. H. Oppenheimer. 1972. A new radioimmunoassay for plasma L-triiodothyronine. Measurements in thyroid disease and in patients maintained on hormonal replacement. J. Clin. Invest. 51:3104-3113.

23. Smith, P. J., and M. I. Surks. 1984. 5,5'-Diphenylhydantoin (Dilantin) decreases cytosol and specific nuclear $\mathrm{T} 3$ binding in rat anterior pituitary in vivo and in cultured GC cells. Endocrinology. 115:283-290.

24. Giles, K. W., and A. Myers. 1967. An improved diphenylamine method for the estimation of deoxyribonucleic acid. Nature (Lond.). 206:93-94.

25. Lowry, O. H., N. J. Rosebrough, A. L. Farr, and R. J. Randall. 1951. Protein measurement with the Folin phenol reagent. J. Biol. Chem. 193:265-275

26. Snedecor, G. W., and W. G. Cochran. 1967. Statistical Methods. Sixth ed., Iowa State. University Press, Ames, IA.

27. Spindler, S. R., S. H. Mellon, and J. D. Baxter. 1982. Growth hormone gene transcription is regulated by thyroid and glucocorticoid hormones in cultured rat pituitary tumor cells. J. Biol. Chem. 257:1162711632.

28. Nyborg, J. K., A. P. Nguyen, and S. R. Spindler. 1984. Relationship between thyroid and glucocorticoid hormone receptor occupancy, growth hormone gene transcription and mRNA accumulation. J. Biol. Chem. 259:12377-12381.

29. Yaffe, B. M., and H. H. Samuels. 1984. Hormonal regulation of the growth hormone gene. Relationship of the rate of transcription to the level of nuclear thyroid hormone-receptor complexes. J. Biol. Chem. 259:6284-6291.

30. Diamond, D. J., and H. M. Goodman. 1985. Regulation of growth hormone messenger RNA synthesis by dexamethasone and triiodothyronine. Transcriptional rate and mRNA stability changes in pituitary tumor cells. J. Mol. Biol. 181:41-52.

30a. Miller, M. J., E. C. Fels, L. E. Shapiro, and M. I. Surks. 1986. Stimulation of growth of cultured GC cells by L-triiodothyronine. Evidence for autocrine regulation. Clin. Res. 34:714a. (Abstr.)

31. Hinkle, P. M., and P. A. Kinsella. 1986. Thyroid hormone induction of an autocrine growth factor secreted by pituitary tumor cells. Science (Wash. DC). 234:1549-1552.

32. Marek; J., M. Schullerova, O. Schreiberova, and Z. Limanova. 1981. Effect of thyroid function on serum somatomedin activity. Acta Endocrinol. 96:491-497.

33. Chernausek, S. D., L. E. Underwood, R. D. Utiger, and J. J. Van Wyk. 1983. Growth hormone secretion and plasma somatomedin-C in primary hypothyroidism. Clin. Endocrinol. 19:337-344.

34. Clemmons, D. R., L. E. Underwood, and J. J. Van Wyk. 1981. Hormonal control of immunoreactive somatomedin production by cultured human fibroblasts. J. Clin. Invest. 67:10-19.

35. Clemmons, D. R. 1984. Multiple hormones stimulate the production of somatomedin by cultured human fibroblasts. J. Clin. Endocrinol. \& Metab. 58:850-856.

36. Binoux, M., A. Faivre-Bauman, C. Lassarre, A. Barret, and A. Tixier-Vidal. 1985. Triiodothyronine stimulates the production of insulinlike growth factors (IGF) by fetal hypothalmus cells cultured in serumfree medium. Brain Res. 353:319-321.

37. Green, L. A., and E. M. Shooter. 1980. The nerve growth factor biochemistry, synthesis and mechanism of action. Annu. Rev. Neurosci. $3: 353-402$.

38. Carpenter, G., and S. Cohen. 1979. Epidermal growth factor. Annu. Rev. Biochem. 48:193-216.

39. Walker, P., M. E. Weichsel, Jr., S. M. Guo, and D. A. Fisher. 1980. Radioimmunoassay for mouse nerve growth factor (NGF). Effects of thyroxine administration on tissue NGF levels. Brain Res. 86:331341.

40. Walker, P., M. E. Weichsel, Jr., S. B. Hoath, R. E. Poland, and D. A. Fisher. 1981. Effects of thyroxine, testosterone and corticosterone on nerve growth factor (NGF) and epidermal growth factor (EGF) concentration in female mouse submaxillary gland. Dissociation of NGF and EGF responses. Endocrinology. 109:582-587.

41. Gresik, E. W., I. Scheukein, H. Van Der Noen, and T. Barka. 1981. Hormonal regulation of epidermal growth factor and protease in the submandibular gland of the adult mouse. Endocrinology. 109:924929.

42. Walker, P., P. Coulombe, and J. H. Dussault. 1982. Time- and dose-dependent effect of triiodothyronine on submaxillary gland epidermal growth factor concentration in adult female mice. Endocrinology. 111:1133-1139.

43. Walker, P., M. E. Weichsel, Jr., D. Eveleth, and D. A. Fisher. 1982. Ontogenesis of nerve growth factor and epidermal growth factor in submaxillary glands and nerve growth factor in brains of immature male mice. Correlation with ontogenesis of serum levels of thyroid hormones. Pediatr. Res. 16:520-524.

44. Walker, P. 1986. Thyroxine increases neonatal mouse submandibular gland mRNA-directed synthesis of epidermal growth factor. Biochem. Cell. Biol. 64:290-296.

45. Siminoski, K., J. Bernanke, C. Kay, and R. A. Murphy. 1986. Steroids and triiodothyronine reduce nerve growth factors concentrations in medium conditioned by L-929 fibroblasts. Endocrinology. 118:14171425.

46. Wion, D., P. Barrand, E. Dicou, J. Scott, and P. Brachet. 1985. Serum and thyroid hormones $T_{3}$ and $T_{4}$ regulate nerve growth factor mRNA levels in mouse L-cells. FEBS (Fed. Eur. Biochem. Soc.) Lett. 189:37-41. 
47. Dickson, R. B., K. K. Huff, E. M. Spencer, and M. E. Lippman. 1986. Induction of epidermal growth factor-related polypeptides by 17 . estradiol in MCF-7 human breast cancer cells. Endocrinology. 118:138142.

48. Vignon, F., F. Capony, M. Chambon, G. Freiss, M. Barcis, and H. Rochefort. 1986. Autocrine growth stimulation of the MCF-7 breast cancer cells by the estrogen-regulated $52 \mathrm{~K}$ protein. Endocrinology. 118 : 1537-1545.

49. Manni, A., M. Pontari, and C. Wright. 1985. Autocrine stimulation by prolactin of hormone-responsive breast cancer growth in culture. Endocrinology. 117:2040-2043.

50. Clemmons, D. R., and J. J. Van Wyk. 1985. Evidence for a functional role of endogenously produced somatomedin-like peptides in the regulation of DNA synthesis in cultured human fibroblasts and porcine smooth muscle cells. J. Clin. Invest. 75:1914-1918.

51. Betscholtz, C., B. Westermark, B. Elk, and C. H. Heldin. 1984. Co-expression of a PDGF-like growth factor and PDGF receptors in a human osteosarcoma cell line: implications for autocrine receptor activation. Cell. 39:447-457.

52. Moses, H. L., E. L. Brauum, J. A. Proper, and R. A. Robinson. 1981. Transforming growth factor production by clinically transformed cells. Cancer Res. 41:2842-2848.

53. Roberts, A. B., M. A. Anzano, L. C. Lamb, J. M. Smith, and M. B. Sporn. 1981. New class of transforming growth factors potentiated by epidermal growth factor: isolation from non-neoplastic tissues. Proc. Natl. Acad. Sci. USA. 78:5339-5343.

54. Meuer, S. C., R. E. Hussey, D. A. Cantrell, J. C. Hodgon, S. F. Schlossman, K. A. Smith, and E. Reinberg. 1984. Triggering of the $T_{3}-$ $\mathrm{T}_{\mathrm{i}}$ antigen-receptor complex results in clonal $\mathrm{T}$-cell proliferation through an interleukin-2-dependent autocrine pathway. Proc. Natl. Acad. Sci. USA. 81:1509-1513.

55. Duprez, V., G. Lenoir, and A. Dautry-Varsat. 1985. Autocrine growth stimulation of a human T-cell lymphoma line by interleukin 2 . Proc. Natl. Acad. Sci. USA. 82:6932-6936. 